\title{
THE INHERITANCE OF CERTAIN CHARACTERS IN OENOTHERA HYBRIDS OF DIFFERENT CHROMOSOME CONFIGURATIONS ${ }^{1}$
}

\author{
STERLING EMERSON \\ California Institute of Technology, Pasadena, California
}

Received June 28, 1930

TABLE OF CONTENTS

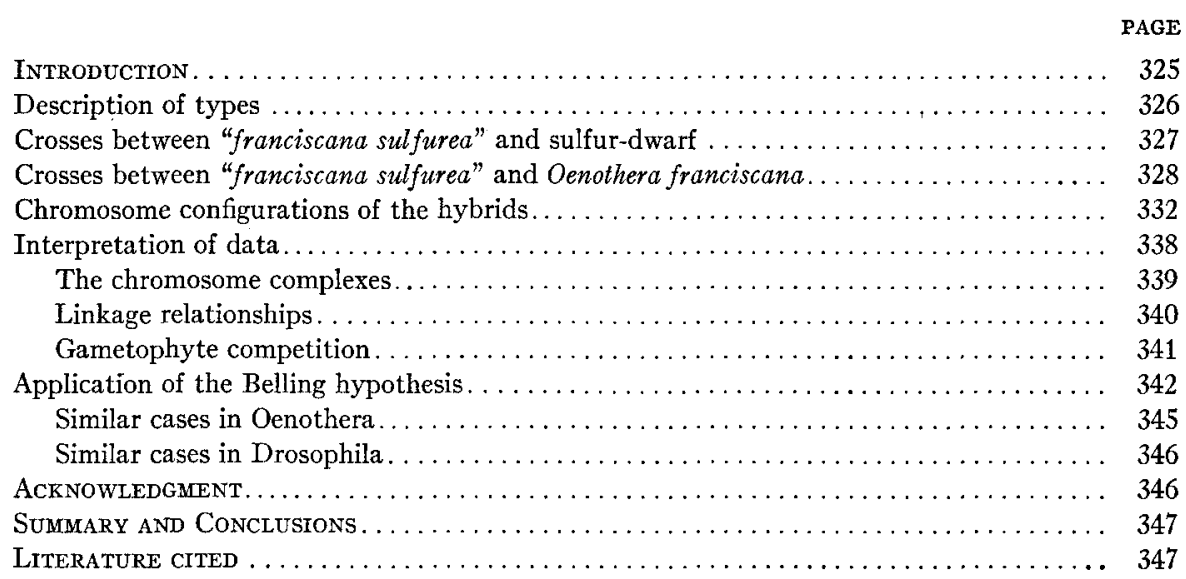

INTRODUCTION

Perhaps the most significant development in the genetics of Oenothera in recent years is the finding of constant differences in the linkage relationships of certain characters and the association of these variations with constant differences in the chromosome configurations of the plants concerned. RENNER (1927) has shown, for example, that in one cross a character may be closely or completely linked to a second character and independent of a third character, while in another cross the first character will be independent of the second and linked to the third. Cleland and Oenlkers (Oehlkers 1926, Cleland and Oenlkers 1929) have found that characters which are independently inherited in hybrids with pairing chromosomes are linked in hybrids in which the chromosomes are associated in large rings during meiosis.

A similar relationship between linkage of characters and association of chromosomes is found in the crosses reported in this paper.

1 Paper from the Department of Botany, University of Michigan, No. 344. 


\section{DESCRIPTION OF TYPES}

\section{Oenothera franciscana}

Oenothera franciscana Bartlett has been grown extensively by Professor DAvis who has described this species in some detail in his paper of 1916. The characters of franciscana that are important in the experiments herein reported are its red bud-cones (figure 1), yellow flowers, and the franciscana growth-habit. Cleland (1922) found that franciscana had five chromosome pairs and a circle of four chromosomes. Since then KuLKarNI (1928) has reported the breaking of the circle into two pairs preceding the heterotypic metaphase. The franciscana plants used in the following experiments were not examined cytologically, but there is evidence (reported below) that one parent plant had the circle of four chromosomes. Oe. franciscana appears to be genetically homozygous and is apparently free from lethals. There are almost no empty or shrivelled pollen grains.

\section{"Franciscana sulfurea"}

The hybrid called "franciscana sulfurea"' arose from the cross Oe. bien" $n i s \times$ franciscana (DAvis 1916). It agrees closely with franciscana in growth habit, but has green bud-cones (figure 1) and sulfur-colored flowers.
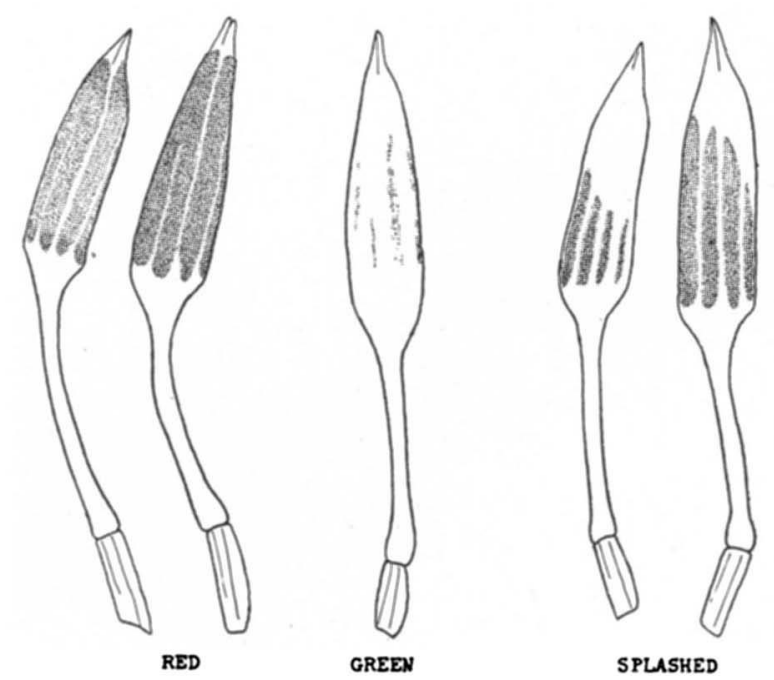

FigURE 1.

${ }^{2}$ This form has also been grown by SHull (1923b) who obtained his material from Professor DAvis, but Professor SHULL's present cultures must represent a secondary derivative of the parent form as his plants have all pairing chromosomes (CLELAND 1927, ILlick 1929) and apparently have red bud-cones-"similar to franciscana genetically except for its sulfur-colored flowers" (ILLICK 1929, p. 614). 
Fifty percent of the pollen grains are empty and shrivelled. Clecand (1924) found a circle of twelve chromosomes and a single free pair in this form. The parents used in the following experiments were not examined cytologically, but the cytology of $F_{1}$ culture 288 (reported below) of the cross with franciscana and of $\mathrm{F}_{1}$ cultures of crosses with Oe. Hookeri suggested that the chromosome configuration of "franciscana sulfurea" had become altered. One plant (650-3), a descendant of the inbred parent of culture 288, happened to be still in flower in our garden in December. This plant was examined by the aceto-carmine method and found to have two pairs of chromosomes and apparently a circle of ten (plate 1). ${ }^{3}$

When inbred, "franciscana sulfurea" regularly produces the parent type and a new form called sulfur-dwarf.

\section{Sulfur-dwarf}

The sulfur-dwarf segregate from "franciscana sulfurea" differs from the parent form in bud color and in stature. It has red bud-cones similar to those of franciscana. In growth-habit it differs from franciscana chiefly in height. The central axis of the dwarf is roughly three-quarters as long as in franciscana. The lateral branches are generally fewer and less erect and the leaves somewhat narrower in the dwarf than in franciscana. Sulfurdwarf has been found to have almost no empty pollen grains, and all of the chromosomes pair regularly (EMERson 1928). Sulfur-dwarf breeds true.

\section{Splashed bud-cones}

A new bud color sometimes appears in crosses between Oe. franciscana and "franciscana sulfurea." The bud-cones are distinctly red, but generally less pigmented than the red bud-cones of franciscana. The greatest difference is in the pattern of the pigmented area. Red bud-cones are strongly pigmented near the tip, while splashed bud-cones are always green near the tip (compare figure 1).

\section{CROSSES BETWEEN "FRANCISCANA SULFUREA" AND}

\section{SULFUR-DWARF}

From self-pollinated "franciscana sulfurea," a culture of 93 plants was grown (culture 394 of 1928), in which were 90 "franciscana sulfurea" plants and 3 sulfur-dwarfs. ${ }^{4}$ The same plant pollinated by sulfur-dwarf yielded

${ }^{3}$ The inbred descendants of $650-3$ have since been examined and found definitely to have a ring of 10 chromosomes and 2 pairs.

"Professor Davis has extensive unpublished data on the genetics of "franciscana sulfurea." He has often found much higher percentages of sulfur-dwarfs in progenies of selfed "franciscana sulfurea." 
132 "franciscana sulfurea" plants and 9 sulfur-dwarfs (culture 397 ). In the reciprocal cross (culture 398) were 64 sulfur-dwarfs and no plants of the "franciscana sulfurea" type.

\section{CROSSES BETWEEN "FRANCISCANA SULFUREA" \\ AND OENOTHERA FRANCISCANA}

Reciprocal crosses between Oenothera franciscana and "franciscana sulfurea" were made in the summer of 1923 , from which $F_{1}$ cultures 58 and 59 were grown the following summer. In 1927, Professor Davis kindly gave me seeds of similar crosses made by him in 1925. From these seeds $F_{1}$ cul-

TABLE 1

$F_{1}$ frequencies in reciprocal crosses between Oenothera franciscana and "franciscana sulfurea."

\begin{tabular}{c|c|c|c|c}
\hline \multirow{2}{*}{ CROSs } & $\begin{array}{c}\text { CULTURE } \\
\text { NUMBER }\end{array}$ & \multicolumn{3}{|c}{ BUD-CONE COLOR } \\
\cline { 2 - 5 } & & RED & GREEN & SPLASHED \\
\hline franciscana $\times$ "franciscana sulfurea" & 58 & 76 & 0 & 0 \\
& 287 & 461 & 0 & 0 \\
& & & & 1 "franciscana sulfurea" $\times$ franciscana \\
& 59 & 14 & 45 & 1 ? \\
& 288 & 255 & 203 & 1 ? \\
\hline
\end{tabular}

TABLE 2

Phenotypic frequencies in $F_{2}$ generations from $F_{1}$ plants with red bud-cones.

\begin{tabular}{|c|c|c|c|c|c|c|c|}
\hline \multirow{2}{*}{$\begin{array}{l}\text { COLTURE } \\
\text { NUMBEER }\end{array}$} & \multicolumn{2}{|c|}{ YFLLOW } & \multicolumn{2}{|c|}{ SOLFUR } & \multirow{2}{*}{$\begin{array}{c}\text { PFRCENT* } \\
\text { OERMMANATION }\end{array}$} & \multirow{2}{*}{$\begin{array}{l}\text { PARENT } \\
\text { PLANT }\end{array}$} & \multirow{2}{*}{$\begin{array}{c}\text { CHROMOSOME } \dagger \\
\text { CONFIGURATION }\end{array}$} \\
\hline & TALL & DWARF & TALL & DWARF & & & \\
\hline 177 & 55 & 1 & 3 & 0 & $?$ & $58-1$ & $\odot 4,5$ pairs \\
\hline 178 & 67 & 5 & 14 & 2 & ? & $59-1$ & 7 pairs \\
\hline 406 & 26 & 15 & 0 & 0 & 68 & $287-3$ & 7 pairs \\
\hline 411 & 45 & 3 & 8 & 0 & 59 & -4 & Unknown \\
\hline 416 & 16 & 2 & 1 & 0 & 33 & -6 & 7 pairs \\
\hline 456 & 45 & 15 & 7 & 1 & 91 & $288-1$ & 7 pairs \\
\hline 461 & 45 & 7 & 2 & 0 & 72 & -2 & Unknown \\
\hline 466 & 51 & 8 & 4 & 0 & 85 & -4 & 7 pairs \\
\hline 470 & 47 & 4 & 1 & 0 & 70 & -10 & Unknown \\
\hline 473 & 45 & 7 & 1 & 1 & 75 & -49 & Unknown \\
\hline Total & 442 & 67 & 41 & 4 & & & \\
\hline
\end{tabular}

* The germination percentages in this and following tables were observed from earth-sown seeds.

$\dagger$ In this and the following tables, the symbol $\odot$ is used to indicate a chromosome circle. The number following the symbol indicates the number of chromosomes in the circle. 
tures 287 and 288 were grown. The pedigrees of $F_{2}$, backcross, and $F_{3}$ generations are given in the following tables (1 to 14) in which the data obtained from these crosses are presented.

TABLE 3

Phenotypic frequencies in the backcross $F_{1}$ (red bud-cones) $\times$ sulfur-dwarf.

\begin{tabular}{|c|c|c|c|c|c|c|c|}
\hline \multirow{2}{*}{$\begin{array}{l}\text { CULTURE } \\
\text { NUMBERE }\end{array}$} & \multicolumn{2}{|c|}{ YELLOW } & \multicolumn{2}{|c|}{ BULFUR } & \multirow{2}{*}{$\begin{array}{c}\text { PERCENT } \\
\text { GERMINATION }\end{array}$} & \multirow{2}{*}{$\begin{array}{l}\text { PARENT } \\
\text { PLANT }\end{array}$} & \multirow{2}{*}{$\begin{array}{l}\text { CHROMOSOME } \\
\text { CONFIGURATION }\end{array}$} \\
\hline & TALL & DWARF & TALL & DWARF & & & \\
\hline 409 & 29 & 28 & 6 & 7 & 97 & $287-3$ & 7 pairs \\
\hline 414 & 11 & 15 & 14 & 15 & 73 & -4 & Unknown \\
\hline 417 & 30 & 29 & 5 & 7 & 95 & -6 & 7 pairs \\
\hline 420 & 34 & 21 & 11 & 4 & 97 & -10 & 7 pairs \\
\hline 425 & 19 & 14 & 20 & 21 & 96 & -31 & 7 pairs \\
\hline 427 & 18 & 18 & 4 & 2 & 96 & -40 & Unknown \\
\hline 428 & 22 & 19 & 10 & 14 & 92 & -51 & Unknown \\
\hline 429 & 29 & 18 & 7 & 9 & 91 & -90 & Unknown \\
\hline 430 & 18 & 20 & 10 & 9 & 97 & -110 & Unknown \\
\hline 431 & 20 & 20 & 7 & 5 & 75 & -140 & Unknown \\
\hline 432 & 30 & 27 & 7 & 6 & 98 & -165 & Unknown \\
\hline 433 & 31 & 33 & 3 & 2 & 96 & -200 & Unknown \\
\hline 457 & 25 & 17 & 5 & 8 & 83 & $288-1$ & 7 pairs \\
\hline 464 & 2 & 1 & 0 & 2 & 57 & -2 & Unknown \\
\hline 467 & 26 & 22 & 14 & 7 & 93 & -4 & 7 pairs \\
\hline 471 & 39 & 18 & 7 & 4 & 92 & -10 & Unknown \\
\hline 474 & 16 & 23 & 5 & 8 & 69 & -49 & Unknown \\
\hline 488 & 13 & 9 & 7 & 7 & 52 & -103 & Unknown \\
\hline 489 & 16 & 13 & 5 & 3 & 53 & -106 & Unknown \\
\hline Total & 428 & 365 & 147 & 140 & & & \\
\hline
\end{tabular}

TABLE 4

Phenotypic frequencies in the backcross sulfur-dwarf $\times F_{1}$ (red bud-cones).

\begin{tabular}{|c|c|c|c|c|c|c|c|}
\hline \multirow{2}{*}{$\begin{array}{l}\text { CULTURE } \\
\text { NUMBER }\end{array}$} & \multicolumn{2}{|c|}{ YELLOW } & \multicolumn{2}{|c|}{ SULFUR } & \multirow{2}{*}{$\begin{array}{c}\text { PERCENT } \\
\text { GERMINATION }\end{array}$} & \multirow{2}{*}{$\begin{array}{l}\text { PARENT } \\
\text { PLANT }\end{array}$} & \multirow{2}{*}{$\begin{array}{l}\text { CHROMOSOME } \\
\text { CONFIGURATION }\end{array}$} \\
\hline & TALL & DWARF & TALL & DWARF & & & \\
\hline 410 & 17 & 10 & 18 & 5 & 72 & $287-3$ & 7 pairs \\
\hline 415 & 8 & 6 & 1 & 1 & 86 & -4 & Unknown \\
\hline 418 & 12 & 15 & 10 & 15 & 72 & -6 & 7 pairs \\
\hline 422 & 8 & 15 & 8 & 5 & 48 & -10 & 7 pairs \\
\hline 424 & 12 & 23 & 9 & 9 & 72 & -19 & Unknown \\
\hline 458 & 10 & 12 & 3 & 3 & 37 & $288-1$ & 7 pairs \\
\hline 465 & 12 & 10 & 7 & 0 & 73 & -2 & Unknown \\
\hline 472 & 3 & 2 & 2 & 2 & 21 & -10 & Unknown \\
\hline 475 & 2 & 3 & 2 & 3 & 16 & -49 & Unknown \\
\hline Total & 84 & 96 & 60 & 43 & & & \\
\hline
\end{tabular}

Genetics 16: J1 1931 
TABLE 5

Phenotypic frequencies in the backcross $F_{1}$ (red bud-cones) $\times$ red sulfur tall.

\begin{tabular}{|c|c|c|c|c|c|}
\hline $\begin{array}{l}\text { CULTURE } \\
\text { NUMBER }\end{array}$ & YELLOW & SULFUR & $\begin{array}{c}\text { PERCENT } \\
\text { GERMINATION }\end{array}$ & $\begin{array}{l}\text { PARENT } \\
\text { PLANT }\end{array}$ & $\begin{array}{l}\text { CHROMOSOME } \\
\text { CONFIGURATION }\end{array}$ \\
\hline 407 & 52 & 12 & 88 & $287-\quad 3$ & 7 pairs \\
\hline 412 & 41 & 18 & 83 & -4 & Unknown \\
\hline 419 & 66 & 12 & 68 & -6 & 7 pairs \\
\hline 434 & 37 & 19 & 77 & -7 & 7 pairs \\
\hline 435 & 55 & 4 & 91 & -8 & Unknown \\
\hline 436 & 49 & 18 & 92 & -9 & Unknown \\
\hline 437 & 52 & 22 & 100 & -12 & Unknown \\
\hline 438 & 43 & 23 & 92 & -13 & Unknown \\
\hline 440 & 34 & 16 & 67 & -33 & Unknown \\
\hline 441 & 22 & 13 & 47 & -34 & Unknown \\
\hline 442 & 24 & 15 & 53 & -36 & Unknown \\
\hline 443 & 26 & 15 & 61 & -37 & Unknown \\
\hline 444 & 10 & 5 & 20 & -38 & Unknown \\
\hline 445 & 36 & 17 & 71 & -201 & Unknown \\
\hline 446 & 20 & 8 & 37 & -202 & Unknown \\
\hline 447 & 38 & 11 & 67 & -203 & Unknown \\
\hline 448 & 12 & 6 & 24 & -204 & Unknown \\
\hline 449 & 31 & 18 & 67 & -205 & Unknown \\
\hline 450 & 34 & 11 & 61 & -206 & Unknown \\
\hline 451 & 27 & 19 & 63 & -207 & Unknown \\
\hline 454 & 30 & 3 & 79 & -211 & Unknown \\
\hline 455 & 20 & 10 & 44 & -212 & Unknown \\
\hline 459 & 52 & 9 & 84 & $288-\quad 1$ & 7 pairs \\
\hline 462 & 56 & 6 & 83 & -2 & Unknown \\
\hline 491 & 48 & 18 & 66 & -81 & Unknown \\
\hline 476 & 53 & 31 & 59 & -89 & Unknown \\
\hline 477 & 19 & 10 & $?$ & -97 & Unknown \\
\hline 490 & 35 & 24 & 61 & -142 & Unknown \\
\hline 478 & 9 & 4 & 17 & -146 & Unknown \\
\hline 479 & 34 & 17 & 68 & -152 & Unknown \\
\hline 480 & 28 & 19 & 65 & -153 & Unknown \\
\hline 481 & 59 & 5 & 73 & -156 & Unknown \\
\hline 482 & 27 & 12 & 41 & -193 & Unknown \\
\hline 483 & 43 & 23 & 69 & -203 & Unknown \\
\hline 484 & 20 & 4 & 32 & -220 & Unknown \\
\hline 485 & 40 & 24 & 87 & -240 & Unknown \\
\hline 486 & 33 & 25 & 81 & -302 & Unknown \\
\hline 487 & 25 & 8 & 44 & -367 & Unknown \\
\hline Total & 1340 & 534 & & & \\
\hline
\end{tabular}


TABLE 6

Phenotypic frequencies in the backcross red sulfur tall $\times F_{1}$ (red bud-cones).

\begin{tabular}{c|c|c|c|c|c}
\hline $\begin{array}{c}\text { CULTURE } \\
\text { NUMBER }\end{array}$ & YELLOW & SULFUR & $\begin{array}{c}\text { PERCENT } \\
\text { GERMINATION }\end{array}$ & $\begin{array}{c}\text { PARENT } \\
\text { PLANT }\end{array}$ & $\begin{array}{c}\text { CHROMOSOME } \\
\text { CONFIGURATION }\end{array}$ \\
\hline 408 & 44 & 20 & 92 & $287-3$ & 7 pairs \\
413 & 32 & 17 & $?$ & -4 & Unknown \\
460 & 40 & 23 & 87 & $288-1$ & 7 pairs \\
463 & 23 & 5 & 65 & -2 & Unknown \\
469 & 51 & 12 & 87 & -4 & 7 pairs \\
\hline Total & 190 & 77 & & & \\
\hline
\end{tabular}

TABLE 7

Phenotypic frequencies in $F_{3}$ generations from $F_{1}$ (red bud-cones) $F_{2}$ red yellow tall.

\begin{tabular}{|c|c|c|c|c|c|c|}
\hline \multirow{2}{*}{$\begin{array}{l}\text { COLTURE } \\
\text { NUMBER }\end{array}$} & \multicolumn{2}{|c|}{ YeLLOW } & \multicolumn{2}{|c|}{ SULFUR } & \multirow{2}{*}{$\begin{array}{l}\text { PARENT } \\
\text { PLANT }\end{array}$} & \multirow{2}{*}{$\begin{array}{l}\text { CHROMOSOMR } \\
\text { CONFIQURATION }\end{array}$} \\
\hline & TALL & DWARF & TALL & DWARP & & \\
\hline 306 & 53 & . & 2 & .. & $178-3$ & Unknown \\
\hline 307 & 108 & . & . & .. & -7 & Unknown \\
\hline 308 & 21 & 0 & 1 & 1 & -9 & Unknown \\
\hline 309 & 71 & 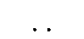 & & . & -10 & Unknown \\
\hline 311 & 47 & . & 4 & .. & -16 & Unknown \\
\hline 324 & 21 & . & . & .. & $177-1$ & Unknown \\
\hline 325 & 63 & .. & . & .. & -3 & 7 pairs \\
\hline 326 & 51 & . & .. & .. & -9 & $\odot 4,5$ pairs \\
\hline 329 & 8 & .. & .. & .. & -24 & $\odot 4,5$ pairs \\
\hline 330 & 66 & .. & .. & $\ldots$ & -29 & Unknown \\
\hline 331 & 34 & .. & 18 & .. & -32 & Unknown \\
\hline 332 & 43 & 13 & .. & .. & -36 & Unknown \\
\hline 333 & 25 & $\ldots$ & 4 & $\ldots$ & -39 & Unknown \\
\hline
\end{tabular}

TABLE 8

Phenotypic frequencies in $F_{3}$ generations from $F_{1}$ (red bud-cones), $F_{2}$ red sulfur tall.

\begin{tabular}{c|c|c|c}
\hline $\begin{array}{c}\text { COLTURE } \\
\text { NUMBER }\end{array}$ & TAIL & DWARF & $\begin{array}{c}\text { PARENT } \\
\text { PLANT }\end{array}$ \\
\hline 334 & 88 & $\ldots$ & $177-61$ \\
335 & 49 & 16 & -59 \\
336 & 55 & 19 & -18 \\
317 & 10 & $\cdots$ & -83 \\
319 & 15 & $\cdots$ & -69 \\
\hline
\end{tabular}


TABLE 9

Phenotypic frequencies in $F_{2}$ generations from $F_{1}$ plants with green bud-cones.

\begin{tabular}{|c|c|c|c|c|c|c|c|c|}
\hline \multirow{2}{*}{ CULTURE } & \multicolumn{2}{|c|}{ GREEN } & \multirow{2}{*}{$\begin{array}{l}\text { SPLASEED } \\
\text { YELLOW }\end{array}$} & \multicolumn{2}{|c|}{ RED } & \multirow{2}{*}{$\begin{array}{l}\text { GERMI- } \\
\text { NATION }\end{array}$} & \multirow{2}{*}{$\begin{array}{l}\text { PARENT } \\
\text { PLANT }\end{array}$} & \multirow{2}{*}{$\begin{array}{l}\text { CHROMOSOME } \\
\text { CONPIGURATTON }\end{array}$} \\
\hline & YELLOW & SULPUR & & YELLOW & SULFUR & & & \\
\hline 180 & 20 & 1 & 1 & 24 & 0 & ? & $59-3$ & Unknown \\
\hline 494 & 23 & 0 & 7 & 43 & 0 & 74 & $288-40$ & Unknown \\
\hline 496 & 43 & 0 & 2 & 64 & 1 & 100 & -5 & $\odot 10,2$ pairs \\
\hline 501 & 17 & 0 & 2 & 29 & 0 & 48 & -6 & Unknown \\
\hline 505 & 18 & 0 & 1 & 29 & 0 & 50 & -7 & Unknown \\
\hline 525 & 20 & 0 & 3 & 25 & 0 & 49 & -20 & $\odot 10,2$ pairs \\
\hline 531 & 1 & 0 & 0 & 23 & 0 & 28 & -29 & Unknown \\
\hline 534 & 0 & 0 & 0 & 3 & 0 & 4 & -60 & $\left\{\begin{array}{l}2 \text { pairs, } 1 \text { tri- } \\
\text { valent, chain } 7\end{array}\right.$ \\
\hline Total & 142 & 1 & 16 & 240 & 1 & & & \\
\hline
\end{tabular}

CHROMOSOME CONFIGURATIONS OF THE HYBRIDS

Cytological examinations were made of two red-budded plants of the $F_{3}$ generations grown in 1924. Of these, one plant (58-1) had a circle of four chromosomes and five chromosome pairs, the other plant (59-1) had seven chromosome pairs. In an $\mathrm{F}_{2}$ culture (177) from 58-1, three plants were examined. Two of these had circles of four chromosome and five pairs, the third had seven chromosome pairs.

From $F_{1}$ cultures grown in 1927 , ten plants with red bud-cones were examined. One plant (287-1) proved to be a haploid (EMERson 1929). The other plants each had seven pairs of chromosomes (plants $287-3,-5,-7$, $-10,-31,288-1,-4$, and -81 ).

Four plants with green bud-cones in the $F_{1}$ cultures of 1927 were examined cytologically. Of these, three plants had each a circle of ten chromosomes and two pairs $(288-5,-20,-71)$, while one plant (288-60) had two chromosome pairs, a trivalent group, and a chain of seven (or eight) chromosomes. Only a few good figures were obtained from plant 288-60, but in each telophase examined there were seven chromosomes in each daughter nucleus. It will be noted in table 9 that self-pollinated seeds of plant 288-60 germinated very poorly. A recent test using about two hundred seeds of this plant gave no germination while seeds of a sister plant still germinated perfectly.

No preparations were obtained from plants with green bud-cones of $F_{1}$ culture 59 .

The chromosome configurations of the various plants listed above are illustrated in plates 1 to 3 . 

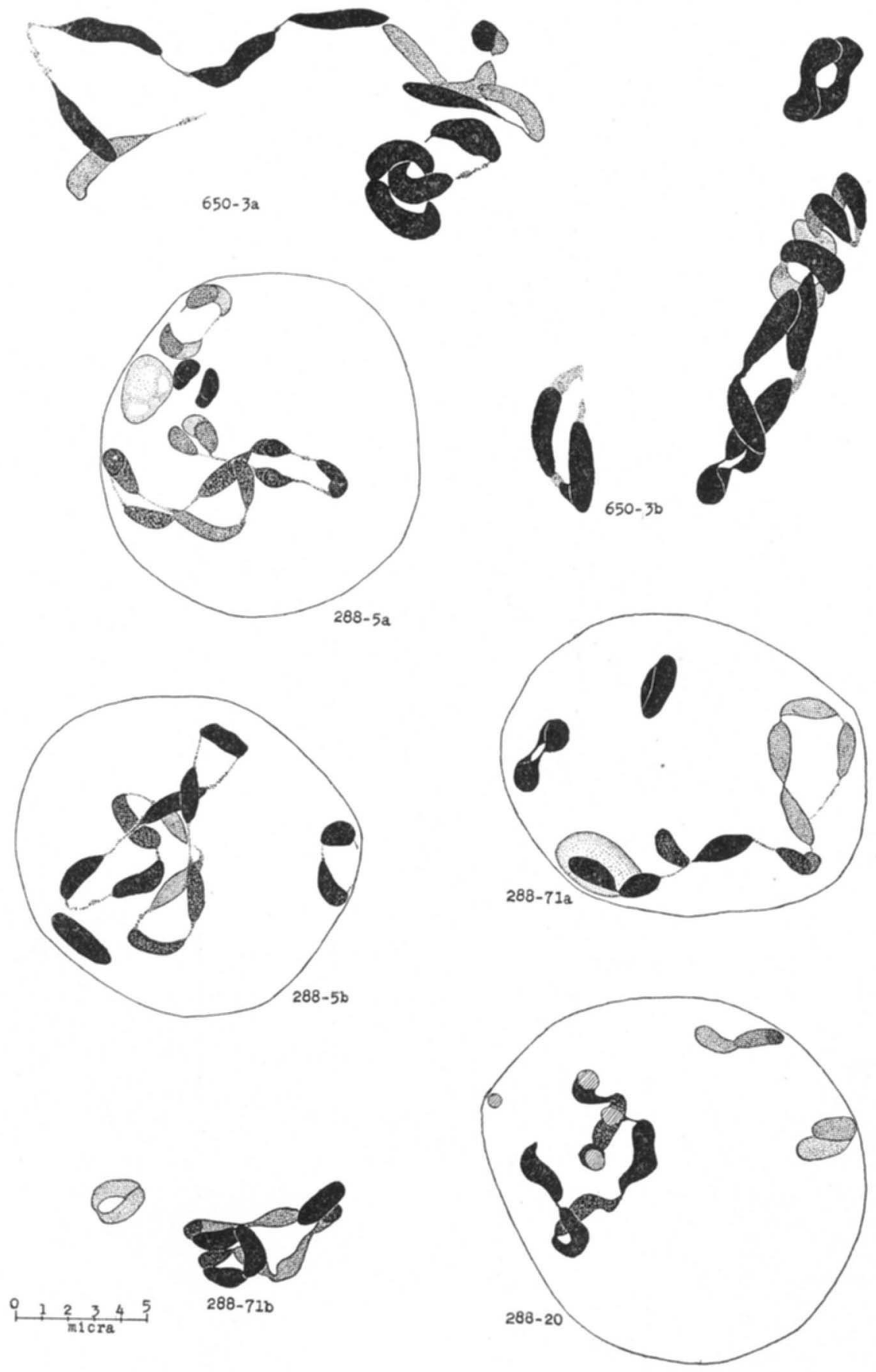

Genetics 16: $333 \mathrm{Jl} 1931$ 
TABLE 10

Phenotypic frequencies in the backcross $F_{1}$ (green bud-cones) $\times$ red sulfur.

\begin{tabular}{|c|c|c|c|c|c|c|c|c|c|}
\hline \multirow{2}{*}{ COLTURE } & \multicolumn{2}{|c|}{ GREEN } & \multicolumn{2}{|c|}{ BPLASEED } & \multicolumn{2}{|c|}{ RED } & \multirow{2}{*}{$\begin{array}{l}\text { GERMII- } \\
\text { NATION }\end{array}$} & \multirow{2}{*}{$\begin{array}{l}\text { PARENT } \\
\text { PLANT }\end{array}$} & \multirow{2}{*}{$\begin{array}{l}\text { CHROMOBOMRR } \\
\text { CONFIGURATION }\end{array}$} \\
\hline & reLLOW & SULFUR & KELLOW & SULFUR & rELLOW & SOLFUR & & & \\
\hline $495^{*}$ & 1 & 1 & 2 & 0 & 28 & 1 & 52 & $288-40$ & Unknown \\
\hline 497 & 3 & 20 & 1 & 0 & 48 & 3 & $77)$ & -5 & $\odot 10,2$ pairs \\
\hline $499^{*}$ & 0 & 18 & 2 & 0 & 52 & 3 & $76\}$ & & \\
\hline 502 & 0 & 5 & 1 & 0 & 26 & 0 & 64 & -6 & Unknown \\
\hline 506 & 1 & 15 & 1 & 1 & 47 & 0 & $69\}$ & -7 & Unknown \\
\hline $508^{*}$ & 3 & 20 & 0 & 1 & 49 & 4 & $82\}$ & & \\
\hline 509 & 0 & 3 & 1 & 0 & 17 & 1 & 24 & -71 & $\odot 10,2$ pairs \\
\hline 510 & 0 & 14 & 3 & 0 & 34 & 2 & 57 & -82 & Unknown \\
\hline 511 & 0 & 6 & 2 & 1 & 35 & 0 & 45 & -83 & Unknown \\
\hline 512 & 0 & 6 & 6 & 0 & 20 & 0 & 34 & -84 & Unknown \\
\hline 513 & 0 & 4 & 2 & 0 & 23 & 1 & 34 & -91 & Unknown \\
\hline 514 & 1 & 22 & 0 & 0 & 33 & 3 & 62 & -92 & Unknown \\
\hline 515 & 1 & 17 & 0 & 1 & 50 & 0 & 69 & -93 & Unknown \\
\hline 516 & 0 & 5 & 1 & 0 & 35 & 1 & 43 & -94 & Unknown \\
\hline 517 & 0 & 8 & 0 & 0 & 16 & 2 & 27 & -99 & Unknown \\
\hline $518^{*}$ & 0 & 11 & 2 & 0 & 20 & 1 & 34 & -101 & Unknown \\
\hline 519 & 0 & 6 & 1 & 0 & 13 & 0 & 23 & -107 & Unknown \\
\hline 520 & 3 & 6 & 0 & 0 & 18 & 1 & 29 & -112 & Unknown \\
\hline 521 & 0 & 2 & 1 & 0 & 35 & 2 & 43 & -120 & Unknown \\
\hline 522 & 3 & 7 & 0 & 0 & 18 & 1 & 30 & -130 & Unknown \\
\hline 523 & 1 & 9 & 0 & 0 & 28 & 2 & 39 & -140 & Unknown \\
\hline 526 & 0 & 2 & 0 & 0 & 4 & 0 & 6 & -85 & Unknown \\
\hline 527 & 0 & 6 & 1 & 0 & 20 & 1 & 28 & -86 & Unknown \\
\hline 528 & 0 & 6 & 1 & 0 & 26 & 3 & 37 & -87 & Unknown \\
\hline $529^{*}$ & 0 & 6 & 1 & 0 & 31 & 1 & 39 & -20 & $\odot 10,2$ pairs \\
\hline $532^{*}$ & 1 & 3 & 0 & 0 & 28 & 0 & 33 & -29 & Unknown \\
\hline 535 & 0 & 4 & 0 & 0 & 7 & 0 & 11 & -60 & $\left\{\begin{array}{l}2 \text { pairs, } 1 \text { tri- } \\
\text { valent, chain } 7\end{array}\right.$ \\
\hline 536 & 2 & 9 & 0 & 1 & 58 & 1 & 76 & -319 & Unknown \\
\hline 537 & 0 & 12 & 0 & 0 & 21 & 0 & 35 & -356 & Unknown \\
\hline 538 & 0 & 2 & 0 & 0 & 16 & 1 & 21 & -143 & Unknown \\
\hline 539 & 0 & 0 & 0 & 0 & 7 & 1 & 8 & -144 & Unknown \\
\hline 540 & 1 & 9 & 1 & 0 & 29 & 3 & 49 & -154 & Unknown \\
\hline 541 & 6 & 7 & 0 & 0 & 33 & 1 & 50 & -259 & Unknown \\
\hline 542 & 0 & 3 & 1 & 0 & 23 & 1 & 30 & -286 & Unknown \\
\hline Total & 27 & 274 & 31 & 5 & 948 & 41 & & & \\
\hline
\end{tabular}

* A culture which was backcross to sulfur-dwarf. Since there were no dwarf segregates from hybrids with green bud-cones, these cultures are listed with the backcrosses to tall red sulfur. 


$$
\begin{aligned}
& \text { 698 } \\
& \text { - } 100 \\
& \begin{array}{ll}
6 & 100 \\
0 & 0 \\
0 & 0
\end{array}
\end{aligned}
$$


TABLE 11

Phenotypic frequencies in the backcross red sulfur $\times F_{1}$ (green bud-cones).

\begin{tabular}{|c|c|c|c|c|c|c|}
\hline \multirow{2}{*}{$\begin{array}{l}\text { CULTURE } \\
\text { NUMBER }\end{array}$} & \multirow{2}{*}{$\begin{array}{l}\text { SPLASHED } \\
\text { YELLOW }\end{array}$} & \multicolumn{2}{|c|}{ RED } & \multirow{2}{*}{$\begin{array}{c}\text { PERCENT } \\
\text { GERMINATION }\end{array}$} & \multirow{2}{*}{$\begin{array}{l}\text { PARENT } \\
\text { PLANT }\end{array}$} & \multirow{2}{*}{$\begin{array}{l}\text { CHROMOSOME } \\
\text { CONFIGURATION }\end{array}$} \\
\hline & & YELLOW & SULFUR & & & \\
\hline 498 & $5 ?$ & 41 & 0 & 61 & & \\
\hline $500^{*}$ & 0 & 1 & 0 & $2\}$ & $288-5$ & $\odot 10,2$ pairs \\
\hline 503 & 1 & 39 & 0 & 91 & & \\
\hline $504^{*}$ & $1 ?$ & 57 & 3 & $80\}^{3}$ & -6 & Unknown \\
\hline 507 & 2 & 38 & 1 & $42\}$ & 7 & \\
\hline $524^{*}$ & 0 & 65 & 0 & 66) & -7 & Unknown \\
\hline $530^{*}$ & 2 & 17 & 0 & 58 & -20 & $\odot 10,2$ pairs \\
\hline $533^{*}$ & 0 & 39 & 0 & 40 & -29 & Unknown \\
\hline Total & $5+6 ?$ & 297 & 4 & & & \\
\hline
\end{tabular}

* A culture which was a backcross to sulfur-dwarf. Since there were no dwarf segregates from hybrids with green bud-cones, these cultures are listed with the backcrosses to tall red sulfur.

TABLE 12

Phenotypic frequencies in $F_{3}$ generations from $F_{1}$ (green bud-cones) $F_{2}$ green yellow.

\begin{tabular}{|c|c|c|c|c|c|}
\hline \multirow{2}{*}{$\begin{array}{l}\text { CULTURE } \\
\text { NOMBER }\end{array}$} & \multicolumn{2}{|c|}{ GREEN } & \multirow{2}{*}{$\begin{array}{l}\text { SPLASHED } \\
\text { YELLOW }\end{array}$} & \multirow{2}{*}{$\begin{array}{c}\text { RED } \\
\text { YELLOW }\end{array}$} & \multirow{2}{*}{$\begin{array}{l}\text { PARENT } \\
\text { PLANT }\end{array}$} \\
\hline & YELLOW & SULPUR & & & \\
\hline 289 & 19 & 0 & 0 & 17 & $180-20$ \\
\hline 290 & 16 & 0 & 0 & 15 & -25 \\
\hline 291 & 20 & 1 & 2 & 10 & -29 \\
\hline 292 & 9 & 0 & 1 & 11 & -37 \\
\hline 293 & 16 & 1 & 0 & 17 & -39 \\
\hline 294 & 18 & 0 & $1 ?$ & 15 & -47 \\
\hline 295 & 4 & 0 & 1 & 24 & -53 \\
\hline Total & 102 & 2 & $4+1 ?$ & 109 & \\
\hline
\end{tabular}

TABLE 13

Phenotypic frequencies in $F_{3}$ generations from $F_{1}$ (green bud-cones) $F_{2}$ red yellow.

\begin{tabular}{c|c|c}
\hline $\begin{array}{c}\text { CULTURE } \\
\text { NCMBER }\end{array}$ & $\begin{array}{c}\text { RED } \\
\text { rELLOW }\end{array}$ & $\begin{array}{c}\text { PARENT } \\
\text { PLANT }\end{array}$ \\
\hline 297 & 125 & $180-2$ \\
298 & 71 & -5 \\
299 & 102 & -8 \\
300 & 99 & -12 \\
301 & 14 & -15 \\
302 & 110 & -16 \\
303 & 111 & -17 \\
305 & 110 & -52 \\
\hline
\end{tabular}




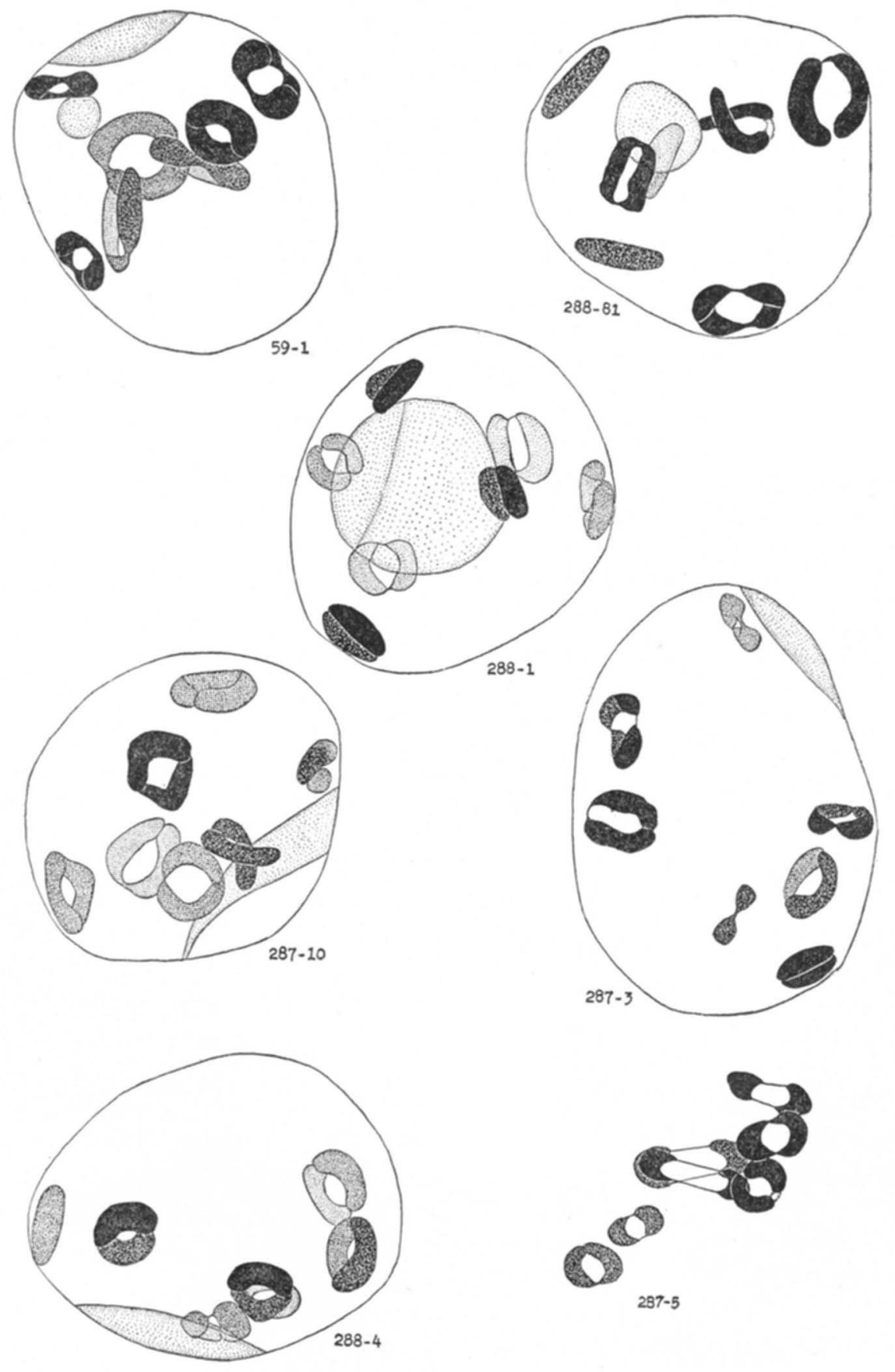

Genetics 16: $337 \mathrm{Jl} 1931$ 


\section{TABLE 14}

Phenotypic frequencies in cultures from self-pollinated plants with splashed bud-cones and of backcrosses to red.

\begin{tabular}{c|c|c|c}
\hline CULTURE & BPLASHED & RED & PARENT \\
\hline A. self-pollinated & & & \\
296 & 83 & 27 & $180-1$ \\
574 & 36 & 54 & $291-1$ \\
575 & 36 & 28 & -31 \\
576 & 38 & 28 & $292-9$ \\
577 & 6 & 6 & $295-21$ \\
581 & 9 & 26 & $296-7$ \\
582 & 8 & 4 & -10 \\
583 & 15 & 28 & -11 \\
584 & 2 & 36 & -12 \\
585 & 3 & 15 & -15 \\
587 & 10 & 11 & -16 \\
589 & 8 & 15 & -17 \\
591 & 8 & 11 & -20 \\
594 & 7 & 16 & -33 \\
\hline Total & 269 & 305 & \\
B. splashedXred & & 47 & $296-7$ \\
580 & 17 & 25 & -15 \\
586 & 18 & 19 & -16 \\
588 & 18 & 21 & -17 \\
590 & 18 & 19 & -21 \\
593 & 26 & 45 & -33 \\
595 & 1 & 135 & \\
\hline Total & 98 & & \\
\hline & & & \\
\hline
\end{tabular}

\section{INTERPRETATION OF DATA}

Yellow flower color has long been known to be dominant to sulfur, and the factor pair $S-s$ is generally used by Oenothera geneticists to represent the relationship of these colors. In the crosses between Oe.franciscana and "franciscana sulfurea," there is always a deficiency in the number of functioning gametes which carry the factor $s$. The gametic ratios obtained in $F_{1}$ plants with pairing chromosomes were $2133: 821(2.6: 1)$ for the eggs and $370: 180(2.1: 1)$ for the pollen (tables 3, 4, 5, and 6). Gametophyte competition such as described by RENNER (1921) might explain the deficiency of the factor $s$ in functioning eggs, and differential pollen-tube growth might be responsible for the deficiency of $s$ in functioning sperms. Neither point was checked by direct experiment.

The dwarf stature of sulfur-dwarf is recessive to the tall stature of 
franciscana and "franciscana sulfurea." This relationship between the two statures will hereafter be represented by the factor pair $D-d$. Gametes carrying $D$ and $d$ respectively are produced in approximately equal numbers in $\mathrm{F}_{1}$ plants with pairing chromosomes. The observed frequencies were $575: 505(1.1: 1)$ for the eggs, and 144:139 (1.03:1) for the sperms (tables 3 and 4$)$.

The green bud-cones of "franciscana sulfurea" are dominant to red. The relationship between these bud colors will be represented by the factor pair $G_{r}-g_{r}{ }^{5}$. The factor $G_{r}$ is always associated with a pollen lethal. The gametic ratios of this factor pair will be discussed in another connection.

Splashed bud-cones are dominant to red, but the character is not discernible in the presence of $G_{r}$. This relationship is shown by the presence of plants with splashed bud-cones in progenies of green-budded plants that were heterozygous for red bud-cones (tables 9,10,11, and 12), and by the presence of red-budded plants in progenies of plants with splashed budcones (table 14). No plants were found that bred true for splashed, indicating a possible association with a lethal factor. The relationship between splashed and red bud-cones will be represented by the factor pair $S_{p t}-S_{p l}$.

\section{The chromosome complexes}

Certain $F_{1}$ plants from crosses between Oe. franciscana and "franciscana sulfurea" have seven pairs of chromosomes. This complete pairing of chromosomes is believed to indicate that franciscana has seven chromosomes (functioning together as a complex) which are the homologs of seven chromosomes constituting one of the complexes of "franciscana sulfurea." The complexes with pairing chromosomes will be called franciscans in franciscana and $s$ - $d$-franciscans in "franciscana sulfurea" as the latter carries factors for sulfur-colored flowers and dwarf stature. All functioning pollen and some of the functioning eggs of "franciscana sulfurea" are $s$-d-franciscans as shown by reciprocal crosses with franciscana and with sulfur-dwarf. Sulfur-dwarf is homozygous for this complex.

The other complex of "franciscana sulfurea" will be called sulfurens. It produces a circle of ten chromosomes and two pairs with franciscans and with $s$-d-franciscans, with which it must therefore have two chromosomes (and only two) in common (that is, homologous).

Oenothera franciscana may produce a second complex which forms a circle of four chromosomes with $s-d$-franciscans as found in $F_{1}$ plant 58-1 and some of its descendants.

\footnotetext{
- The author follows ReNNer (1925) in reserving the factor pair $R-r$ [used by SHuLI (1923a) for bud color] to denote nerve (vein) color, for which it had previously been used by HERIBERTNILSSON. RENNER's factor $S_{t r}$ denotes a dominant red bud-color.
}

GeNetics 16: Jl 1931 


\section{Linkage relationships}

Oenothera "franciscana sulfurea" produces only two types of gametes, sulfurens (carrying factors for sulfur-colored flowers, tall stature, green bud-cones, and a pollen lethal) and $s$-d-franciscans (carrying factors for sulfur-colored flowers, dwarf stature, and red bud-cones). No recombinations of the factors for stature, bud color (red versus green) and the pollen lethal have been found in the gametes of "franciscana sulfurea" as shown by inbred and out-cross cultures.

First generation plants with green bud-cones in the cross "franciscana sulfurea" $\times$ franciscana produce for the most part the two parental types of gametes. These gametes are sulfurens (carrying factors for sulfur-colored flowers, tall stature, green bud-cones, and a pollen lethal) and franciscans (carrying factors for yellow flowers, tall stature, and red bud-cones). No recombinations between bud color and the pollen lethal were obtained. Between bud color and flower color, however, some recombinations occurred. The observed gametic ratios were $27 G_{r}-S: 274 G_{r}-s: 979 g_{r}-S: 46$ $g_{r}-s$ for the eggs, and $308 g_{r}-S: 4 g_{r}-s$ for the sperms (tables 10 and 11). Of the eggs carrying the pollen lethal and factor for green bud-cones, 9 percent represent recombinations with the factor for yellow flowers, while 4.5 percent of the eggs carrying the factor for red bud-cones were recombinations with the factor for flower color, and but 1.28 percent of the sperms represent recombinations between these factors.

In sulfurens of "franciscana sulfurea" there is also a factor for splashed bud-cones $\left(S_{p l}\right)$ closely associated with $G_{r}$ and $s$. In $F_{1}$ plants with green bud-cones (sulfurens franciscans), 3.5 percent of the eggs carrying $g_{r}$ represent recombinations with $S_{p l}$ (gametic ratio is $989 g_{r}-s_{p l}: 36 g_{r}-S_{p l}$, table 10) and 3.5 percent or less ${ }^{6}$ of the sperms carrying $g_{r}$ represent recombinations with $S_{p l}$. In the same egg cells (carrying $g_{r}$ ) there was 7 percent recombination between $S_{p l}$ and $S$ (gametic ratio $953 S_{p l}-s+s_{p l}-S: 72 S_{p l}$ $\left.-S+s_{p l}-s\right)$.

The percentages of recombinations between these three factors might appear to be a function of a linear order of the three genes in a single chromosome. In this case the order of the genes would be:

$\begin{array}{cccc}s_{p l} \quad(3.5) & g_{r} & (4.5) & s \\ (\text { region 1) } & & (\text { region 2) }\end{array}$

${ }^{6}$ The plants in some cultures listed in table 11 were not in their best condition at the time notes were taken, and some plants listed as having splashed bud-cones may have been red but with the pigmentation poorly developed as is often the case when plants first come into flower. Plants for which the classification was difficult are listed in the tables under "splashed" and followed by a question mark (?). 
The observed crossover frequencies would then be: 948 non crossovers $\left(s_{p l}-g_{r}-S\right), 31$ single crossovers in region $1\left(S_{p l}-g_{r}-S\right), 41$ single crossovers in region $2\left(s_{p l}-g_{r}-s\right)$, and 5 double crossovers $\left(S_{p l}-g_{r}-s\right.$ ) (table 10). Expressed in percentages, the frequencies of crossing over are 3.02 singles in region $1,4.00$ in region 2 , and 0.49 doubles. There can thus be no interference between crossing over in regions 1 and 2 .

No crosses were made in which the associations of factors for flower color $(S-s)$ and for stature $(D-d)$ could be studied in plants of the constitution sulfurens.d-franciscans. But since $s_{p l}-g_{r}-d$ are almost completely associated in sulfurens. $s-d-$ franciscans, and since $s_{p l}-g_{r}-S$ are very closely associated in sulfurens franciscans, it may fairly be concluded that $s$ and $d$ are actually closely associated in these hybrids.

In franciscans $\cdot s$ - $d$-franciscans, however, $s$ and $d$ are completely independent. In the eggs there was 47.4 percent recombination between flower color and stature (gametic ratio $568 D-S+d-s: 512 D-s+d-S$, table 3 ), while in the sperms there was 51.6 percent recombination (gametic ratio $127: 156$, table 4). The independence of $s$ and $d$ is further borne out by the segregation of $F_{3}$ cultures (tables 7 and 8).

In considering the differences in association of $s$ and $d$ in these crosses, it must be borne in mind that franciscans $s$-d-franciscans has all pairing chromosomes, while sulfurens.franciscans and sulfurens.s-d-franciscans each have ten chromosomes in a circle. It is reasonable to suppose that the linkage of factors in the latter hybrids is due to the association of chromosomes in a circle.

\section{Gametophyte competition}

RENNER (1921) has shown that in many cases in which two dissimilar complexes are segregating in megasporogenesis, the megaspores receiving one complex have a distinct advantage over the other type of megaspore in their ability to develop into gametophytes (embryo-sacs). This superiority of the first complex may not hold when it is competing against a third complex.

Competition of this nature is to be seen in crosses involving Oe. "franciscana and franciscana sulfurea." In the "franciscana sulfurea" plant used in the crosses of 1923, the frequencies of the two types of complexes functioning as eggs were 45 sulfurens and $15 s$-d-franciscans (culture 59 in table 1). In the $F_{1}$ plant 59-3, involving the same sulfurens complex against francis. cans, the gametic ratio was 21 sulfurens:25 franciscans (culture 180 in table 9). In $F_{2}$ plants of culture 180, the gametic ratio was 104 sulfurens: 114 franciscans. These data are interpreted as indicating that the sulfurens 
used in 1923 had a marked superiority over $s$-d-franciscans and none over franciscans.

In the cross of 1925 , the gametic ratio in the "franciscana sulfurea" plant used was 203 sulfurens:256 s-d-franciscans (culture 288 in table 1). In $F_{1}$ plants involving the same sulfurens against franciscans, the gametic ratio was 122 sulfurens: 232 franciscans. In this case both franciscans and $s$-d-franciscans are superior to sulfurens, but franciscans is stronger than s-d-franciscans as in the previous case.

The sulfurens in the cross of 1923 may have been the original type which formed a circle of twelve with $s-d$-franciscans, while that used in 1925 had become altered to form a circle of ten. Such a difference might account for the divergent results in the crosses of 1923 and 1925.

\section{APPLICATION OF THE BELIING HYPOTHESIS}

HÅKANSSON (1928) and DARLINGToN (1929) have shown that the hypothesis (BELLING 1927) of attraction of chromosomes into circles by rearrangements (translocations) of homologous ends will give a mechanical explanation of most of the genetical and cytological phenomena of the Oenotheras. It is not the purpose of the present paper to review the application of BeLling's hypothesis to the Oenotheras, but the hypothesis offers an alternative explanation of the linkage relationships reported above which is in many respects superior to that afforded by the presence of the genes in a single chromosome.

In order to avoid the use of permanent names for the ends of the chromosomes until more information is available concerning the homologies in different species, the homologous portions of the chromosomes in the accompanying diagrams (plate 4 ) are indicated by differences in shading.

Figure 1 in the diagrams represents the chromosomes of an $F_{1}$ plant with green bud-cones (sulfurens.franciscans) of the cross "franciscana sulfurea" $\times$ franciscana. It will be noted that each chromosome part is present in the diploid condition. In pairing chromosomes, the parts have identical arrangements; but of the chromosomes in the circle, no two have the same combination of parts. The right end of any chromosome in the ring has its counterpart in the left end of the chromosome on its right, while the counterpart of the left end of the first chromosome is the right end of the chromosome to its left. It is this arrangement of homologous portions of the chromosomes, according to the BeLLING hypothesis, which brings the chromosomes into the circle by the attraction between homologous parts. 


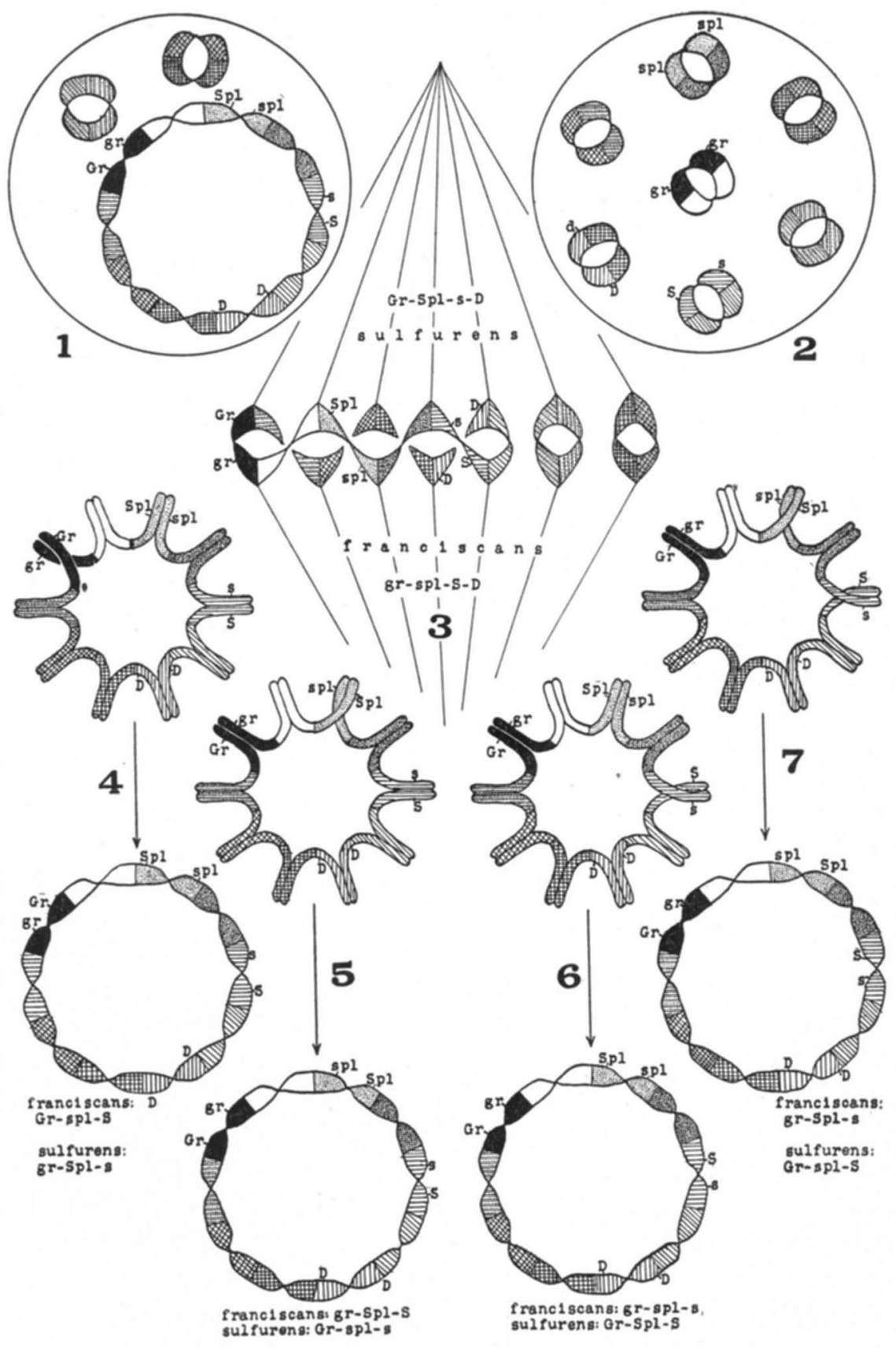


Figure 2 represents the chromosomes of an $\mathrm{F}_{1}$ plant with red bud-cones (franciscans.s-d-franciscans) in which all the chromosomes pair.

Figure 3 illustrates the method of separation of the chromosomes of figure 1 in heterotypic metaphase. CLELAND discovered that the chromosomes in a circle in Oenothera regularly separate by a zig-zag arrangement of the chromosomes on the metaphase plate, so that alternate chromosomes pass to the same pole. BELLING's hypothesis gives a mechanical explanation of the presence of the chromosomes of one complex in the alternate positions in the circles which necessitates the zig-zag arrangement of chromosomes on the spindle to insure the separation of homologous chromosome parts. It has long been known from genetic data that the paternal and maternal gametes separate as a whole in the reduction division of some Oenotheras.

The positions of the genes in the chromosomes have been chosen arbitrarily. The scheme requires that the genes be in different chromosome parts, but there is no method of determining the position of any gene in the circle with the present data.

It will be noted that the genes will appear to be completely linked even though they lie in different chromosomes, unless there are interchanges (crossovers) between homologous chromosome parts. Such crossovers are represented schematically in figures $4,5,6$, and 7 .

Crossovers of this type do not alter the chromosome configurations, but the allelomorphs present in the two complexes are exchanged. Figure 4 represents a crossover involving $G_{r}-g_{r}$ in which $G_{r}$ passes into franciscans and becomes associated with $s_{p l}$ and $S$. The same association of $G_{r}-s_{p l}-S$ can be obtained by crossovers involving $s_{p l}$ and $s$ simultaneously (figure 7 ), but in the latter case $G_{r}-s_{p l}-S$ would be in sulfurens.

In this scheme, percent of crossing over would not be a function of the distance between the two genes appearing as recombinations, but a function of the distances between each of the genes and the respective breaks in the chromosomes (that is, the points at which the chromosomes cease to be homologous to the members on their left and become homologous to the chromosomes on their right). Recombinations between $G_{r}$ and $S_{p l}$ should be equal to the frequency (a) of crossovers between $G_{r}$ and the break in that chromosome, plus the frequency (b) of crossovers between $S_{p l}$ and the break in that chromosome, less the frequency (ab) of simultaneous crossovers between these factors and their corresponding "breaks." Similarly, if $\mathrm{c}$ is the frequency of crossovers between $s$ and the corresponding break, the number of recombinations between $s$ and $S_{p l}$ must be b+cbc, and between $s$ and $G_{r}$ must be a $+\mathrm{c}-$ ac. Crossovers in chromosome 
parts lying between any two genes have no effect on the recombinations of these genes. By substituting the observed frequencies of recombinations in each of these equations and solving for $a, b$, and $c$, one finds the following values for crossing over between the genes and the corresponding breaks: $G_{r}=0.5$ percent, $S_{p l}=3.0$ percent, and $s=4.0$ percent.

Interference in crossing over would have little effect on the frequencies of any crossover class, if crossing over occurs in the manner just described. "Double" crossovers are comparatively rare, and the same combination of genes is obtained by a different single crossover.

In plants of the constitution sulfurens.s-d-franciscans, $G_{r}, S_{p l}$, and $D$ have been found to be closely linked with no recombinations occurring between $G_{r}$ and $D$, while in sulfurens.franciscans $G_{r}, S_{p l}$ and $s$ are clcsely linked, but in franciscans. $s$-d-franciscans, $d$ and $s$ are independent. These results are easily explained by the scheme just described if one assumes that $G_{r}$ and $D$ both lie comparatively close to the breaks in their respective chromosomes. These positions would prevent recombinations in sulfurens. $s$-d-franciscans in which the chromosomes are in a circle, and would permit free recombination in franciscans. $s$-d-franciscans in which the chromosomes pair.

\section{Similar cases in Oenothera}

Crossing over between homologous chromosomes, as described above, may be the cause of the appearance of such mutations as biennis sulfurea from Oe. biennis, nanella from Oe. Lamarckiana, and formosa from Oe. pratincola (strain E).

In the first case, Oe. biennis is known to be balanced for sulfur (OEHLKERS 1924), and the mutation, biennis sulfurea, still has the peculiar chromosome configuration of the parent form (ClELAND 1926).

The second case fulfills the same two conditions. Lamarckiana is balanced for nanella (carried in gaudens). I do not know if the chromosome configuration of nanella has been observed, but there is excellent genetic evidence that nanella forms velans and gaudens complexes which are identical to those of Lamarckiana except for the presence of the nanella factor in velans (RENNER 1925).

Oenothera pratincola (strain E) is known to be balanced for revolute leaves (Совв and BARTlett 1919, Совв 1921). Mutation formosa (revolute-leaved) and pratincola have the same chromosome configuration

${ }^{7}$ The albicans complex of biennis carries sulfur, but due to the presence of balanced zygotic lethals, albicans does not appear in homozygous condition, and the dominant yellow allelomorph in rubens masks the presence of sulfur. 
(KULKaRni 1928). Thus again, the two conditions required by the method of crossing over described above are fulfilled. In this last case, however, the genetic data of Doctor BLANCHARD (СоBB 1921) do not entirely agree with present predictions. Plants with the complexes of formosa (one, however, recovered from a cross with pratincola-C) but heterozygous for revolute behave in their breeding as if the factor for revolute were in a chromosome pair separate from the large complexes. No free pair is expected if the above interpretation is correct.

\section{Similar cases in Drosophila}

As a result of X-ray treatment, Dobzhansky and Sturtevant (1930) have obtained reciprocal translocations between the second and third chromosomes of Drosophila melanogaster. While the cytology of the reduction divisions has not been completed, the somatic pairing of chromosomes in the Diptera gives a good indication of the configuration that the chromosomes must assume during reduction. In somatic cells of flies having one normal second, one normal third, and the two reciprocally translocated chromosomes, the four chromosomes often form a ring. Genetic evidence shows that alternate chromosomes of the ring pass to the same pole in the majority of cases, thus agreeing with the cytological findings for Oenothera.

As the paper of Dobzhansky and Sturtevant includes a discussion of the relation of their findings to the problems of Oenothera genetics, it is necessary here only to point out that there is increasing genetical and cytological data in support of BELLING's hypothesis for ring formation. Dobzhansky and StURTEVANT did not collect linkage data that is completely comparable to that reported above for Oenothera, but it is evident that such data would be obtained if the linkage of genes in three chromosome-halves were studied together. ${ }^{8}$

\section{ACKNOWLEDGMENT}

The studies on Oenothera reported above were undertaken under the direction of Professor H. H. BartLett and Professor B. M. Davis. I am

${ }^{8}$ Since this paper went to press $I$ have studied the crossing over between the four limbs of Doвzhanskx's reciprocal translocations $A, B$, and $C$. All gave the predicted results and agree with the linkage observed for $S_{p l}-b_{r}-s$ reported above for Oenothera. For example: in translocation II-III B, $B_{l}$ lies to the right of the "break" in chromosome II, $p^{p}$ to the left of the "break" in III and $s_{t}$ to the right. From the linkage data, the three genes might lie in a single chromosome in the order $s_{t}-B_{l}-p^{p}$ with 6.39 percent single crossover in region $1,1.86$ percent in region 2 and 0.40 percent double (total 2051 flies) when only 0.15 percent double would be expected if there were no interference. In the Oenothera cross reported above there were 0.49 percent double when only 0.17 percent would be expected with no interference. 
indebted to Professor Davis for the use of his cultures and especially for seed of crosses made by him. I am indebted to Mr. C. O. ERLanson, Mr. W. C. SteEre, and Miss Elizabeth Griffiths for assistance in the cytological part of the investigation.

\section{SUMMARY AND CONCLUSIONS}

Oenothera franciscana may produce two chromosome complexes which together form a ring of four chromosomes. One of these complexes is called franciscans.

Hybrid "franciscana sulfurea" produces a complex of which all the chromosomes are homologous to those of franciscans, since plants composed of these two complexes give seven pairs of chromosomes. This complex of "franciscana sulfurea" differs from that of franciscana by recessive factors for dwarf stature and sulfur-colored flowers and is called $s$ - $d$-franciscans.

The second complex of "franciscana sulfurea" is called sulfurens. Sulfurens forms a circle of ten chromosomes and two pairs with each of the two franciscans-types of complexes.

In crosses involving the three complexes just named, four factor pairs were concerned. These factors were $D-d, S-s, G_{r}-g_{r}$ (a dominant green bud color), and $S_{p l}-s_{p l}$ (splashed bud color, dominant to red).

In sulfurens.s-d-franciscans with a circle of ten chromosomes, $G_{r} S_{p l}$, and $D$ are closely linked. In sulfurens franciscans with a circle of ten chromosomes, $G_{r}, S_{p l}$, and $s$ are closely linked. But in franciscans.s-d-franciscans which has all pairing chromosomes, $s$ and $d$ are completely independent. This relationship is believed to show that the linkage of $D$ and $s$ to $G_{r}$ and $S_{p l}$ in the first two hybrids is due to the association of a large number of chromosomes in a circle in each.

The interpretation that the linkage of $G_{r}, S_{p l}$, and $s$ in sulfurens.franciscans is due to the presence of the three genes in one chromosome is inadequate in that it does not account for the excessive number of observed "double crossovers."

Crossing over between homologous parts of dissimilar chromosomes in the circle of ten in sulfurens.franciscans, however, does account for all the observed genetic behavior. Crossing over of this type presupposes the correctness of BELLING's hypothesis for the attraction of chromosomes into rings due to homologous chromosome-ends.

\section{LITERATURE CITED}

Beling, JoHn, 1927 The attachments of chromosomes at the reduction division in flowering plants. J. Genet. 18: 177-205.

GENETICS 16: Л 1931 
Clem.and, Ralph E., 1922 The reduction divisions in the pollen mother cells of Oenothera franciscana. Amer. J. Bot. 9: 391-413.

1924 Meiosis in the pollen mother cells of Oenothera franciscana sulfurea. Bot. Gaz. 77: 149-170.

1926 Meiosis in the pollen mother cells of Oenothera biennis and Oenothera biennis sulfurea. Genetics 11: 127-162.

1927 The genetics of Oenothera in relation to chromosome behavior, with special reference to certain hybrids. Proceedings of the 5th International Congress, Supplementband of the Z. indukt. Abstamm.- u. VererbLehre. 1: 554-567.

Cleland, Ralph E., and Oehlkers, Fr., 1929 New evidence bearing upon the problem of the cytological basis for genetical peculiarities in the Oenotheras. Amer. Nat. 63: 497-510.

СовB, FRIEDA, 1921 A case of Mendelian inheritance complicated by heterogametism and mutation in Oenothera pratincola. Genetics 6: 1-42.

CoBb, FRIEdA, and BARTLEtT, H. H., 1919 On Mendelian inheritance in crosses between massmutating and non-mass-mutating strains of Oenothera pratincola. J. Wash. Acad. Sci. 9: 462-483.

Daritngton, C. D., 1929 Ring-formation in Oenothera and other genera. J. Genet. 20: 345-363.

Davis, Bradiey MoORE, 1916 Hybrids of Oenothera biennis and Oenothera franciscana in the first and second generations. Genetics 1: 197-251.

Dobzhansky, Th., and Sturtevant, A. H., 1930 Translocations between the second and third chromosomes of Drosophila and their bearing on Oenothera problems. In press.

Emerson, Sterling H., 1928 Chromosome configuration in a dwarf segregate from Oenothera "franciscana sulfurea." Pap. Mich. Acad. Sci. 9: 117-120.

1929 The reduction division in a haploid Oenothera. La Cellule. 39: 159-165.

HÅKansson, ARtur, 1928 Die Reduktionsteilung in den Samenanlagen einiger Oenotheren. Hereditas 11: 130-181.

IlLICK, J. T., 1929 A cytological study of meiosis in the pollen mother cells of some Oenotheras. Genetics 14: 591-633.

Kulkarni, Chandratant G., 1928 Meiosis in Oenothera franciscana. Pap. Mich. Acad. Sci. 9: $223-226$.

1929 Meiosis in pollen mother cells of strains of Oenothera pratincola Bartlett. Bot. Gaz. 87: 218-258.

Oenlkers, Fr., 1924 Das Sulfurea-Merkmal bei den Önotheren. Biol. Zbl. 44: 1-9.

1926 Erblichkeit und Zytology einiger Kreuzungen mit Oenothera strigosa. Jahrb. wiss. Bot. 65: 401-446.

1921 Heterogamie im weiblichenGeschlecht und Embryosackentwicklung bei den Oenotheren. Z. Bot. 13: 609-621.

RenNer, O., 1925 Untersuchungen über die faktorielle Konstitution einiger komplexheterozygotischer Önotheren. Bibl. genet. 9: 1-168.

1927 Über Koppelungswechsel bei Oenothera. Proceedings of the 5th International Congress, Supplementband of the Z. indukt. Abstamm.- u. VererbLehre. 2: 1216-1220.

ShUld, GEORge H., 1923a Linkage with lethal factors the solution of the Oenothera problem. Eugenics, Genetics and the Family 1: 86-99.

1923b Further evidence of linkage with crossing over in Oenothera. Genetics 8: 154-167. 